Юрій Мудрак

Центр воєнно-стратегічних досліджень Національного університету оборони України імені Івана Черняховського, Київ

ORCID ID 0000-0002-1159-5746

Юрій Піщанський

Центр воєнно-стратегічних досліджень Національного університету оборони України імені Івана Черняховського, Київ ORCID ID 0000-0003-4392-3318

Микола Іваницький кандидат військових наук, доцент кафедра керівництва військами (силами) в мирний час Національного університету оборони України імені Івана Черняховського, Київ

ORCID ID 0000-0001-5137-6591

DOI: $10.33099 / 2617-1775 / 2021-01 / 192-202$

\title{
ШЛЯХИ НАБЛИЖЕННЯ ОБОРОННОЇ ТА ВІЙСЬКОВОЇ ОСВІТНЬОЇ СФЕР УКРАЇНИ ДО СТАНДАРТІВ НАТО
}

У статті розглянуто досвід НАТО у сферах оборони та військової освіти з метою його використання при плануванні розвитку Міністерства оборони України, Збройних Сил України та інших складових сил оборони, та наближення їх функціонування до принципів $i$ стандартів, прийнятих у арміях держав-членів НАТО.

Ключові слова: військова освіта, Збройні Сили Украӥни; підготовка; спроможності.

Постановка проблеми. Оборонна реформа, яка продовжується в Україні, має за мету набуття та підтримання силами оборони необхідного рівня бойової готовності і здатності до виконання завдань оборони держави (оборонних спроможностей), ефективного реагування на виникаючі воєнні загрози й воєнно-політичні виклики національній безпеці, підвищення рівня оперативної сумісності Збройних Сил України та інших військових формувань 3 підрозділами збройних сил держав-членів НАТО та ЄС до виконання спільних завдань в міжнародних операціях із підтримання миру і безпеки [1].

Освіта в цій військовій справі є основою інтелектуального, духовного, фізичного і культурного розвитку особистості, іiі успішної соціалізації, економічного добробуту, запорукою розвитку суспільства, об'єднаного спільними цінностями і культурою, та держави [2].

Окремі питання стосовно продовження оборонної реформи, шляхів розвитку Збройних Сил України та військової освіти в контексті наближення їх до принципів і стандартів НАТО розглянуті у наукових працях I. Руснака, А. Петренка, А. Павліковського, В. Фролова, Ф. Саганюка, А. Іващенка та ін. [3-5].

Однак їх підходи нині доцільно наблизити до наявних потреб сучасності та принципів і стандартів НАТО. В умовах триваючої російської агресії проти 
України, як визначив Міністр оборони України, перед нами стоять надважливі завдання, від якості виконання яких, без перебільшення, залежить майбутне нашої країни. Це, розвиток Збройних Сил України та посилення їх бойових спроможностей, переоснащення українського війська, забезпечення його новітніми зразками озброєння та військової техніки, запровадження стандартів НАТО у повсякденну діяльність військ [6].

Переведення управлінських процесів та засад функціонування Збройних Сил України на нову доктринальну базу до кінця 2022 року є амбітною метою оборонної реформи. Це вимагає підготовки фахівців, спроможних діяти відповідно до її положень. У Збройних Силах України має бути запроваджений новий стиль військового лідерства, нова філософія відносин у військових колективах, а також зміна військової культури [7].

Метою статті $\epsilon$ пошук ефективних підходів до вирішення визначених Міністерством оборони України завдань, наближення розвитку Збройних Сил України та їх функціонування до принципів і стандартів, прийнятих у арміях розвинутих держав-членів НАТО.

Аналіз останніх досліджень і публікацій. Зміна парадигми оборонного планування, перехід до моделі планування на основі спроможності військ (сил) (Capability-Based Defense Planning-CBDP) (далі-OПОС), де формується потреба у спроможностях, що необхідні Збройним Силам України стримування противника та нанесення йому поразки, потребує грунтовнішого вивчення передового досвіду держав-членів НАТО, у першу чергу, де такий метод успішно запроваджений і використовується на практиці.

Для впровадження зазначеного підходу у оборонній сфері та сфері військової освіти важливим завданням наукової діяльності $\epsilon$ формування сучасного наукового кадрового потенціалу, здатного забезпечити розвиток наукового прогресу у військовій галузі. [8].

На теперішній час новітні підходи з врахуванням досвіду держав-членів НАТО активно впроваджуються Міністерством оборони України, Збройними Силами України та іншими складовими сил оборони з метою наблизити їх розвиток та функціонування до принципів і стандартів, прийнятих у державахчленах НАТО.

Дослідженню зазначеного процесу у державах-членах НАТО присвячена низка публікацій і документів. Наприклад, у [9] досліджені шляхи та підходи до імплементації основних норм Стратегічної концепції НАТО в Комплексній політичній директиві HATO (Comprehensive Political Guidance), прийнятій державами-членами НАТО, яка забезпечує єдність підходів усіх членів Альянсу для досягнення спільної мети. Директива визначає пріоритети трансформації Альянсу, спрямовані на ефективне виконання операцій, вдосконалення потенціалів, трансформацію сил i засобів, структурну реорганізацію, вдосконалення процесу генерування сил, розвиток спроможності планування й розвідки та відповідного фінансування.

У [10] йдеться про те, що структура (модель) ОПОС НАТО у загальному вигляді в літературі визначена двояко, а саме, як сукупність взаємозалежних процесів та процедур, тобто оцінювання воєнно-політичної обстановки, 
планування сил та ресурсів, управління ризиками; а також, як сукупність процесів довго-, середньо- та короткострокового планування, тобто документів, які відпрацьовуються 3 позиції методичного обгрунтування основних їхніх положень.

У [11] йдеться про необхідність розроблення в Україні для запровадження принципів і стандартів НАТО відповідних організаційних і методичних заходів та документів, у тому числі і з питань вдосконалення всебічного забезпечення оборонної та військово-освітньої сфер.

Упровадження передового досвіду держав-членів НАТО в Україні, особливо 3 питань імплементації законодавчих та інших концептуальних документів, потребує більш детального вивчення для вдосконалення оборонного менеджменту з цього напряму.

Виклад основного матеріалу. Аналіз досвіду та ефективності стандартів НАТО, особливо для врегулювання сучасних воєнних конфліктів показав, що вони є дієвим способом підвищення спроможностей національних сил оборони у протидії з “гібридним” агресором [12, с. 154].

НАТО з цих питань визначило ще один шлях, спрямований на зміцнення спроможності сектору безпеки і оборони країн-партнерів, які не є членами Альянсу. Ця нова ініціатива отримала назву “підтримка сил безпеки і оборони” (Security Force Assistance, SFA). Для реалізації цієї нової ініціативи Альянс ухвалив низку керівних документів (рис. 1).

\section{Керівні документи Security Force Assistance}

\begin{tabular}{|c|c|c|c|c|}
\hline \multicolumn{2}{|c|}{$\begin{array}{c}\text { Концепція } \\
\text { (MCM-0034-2014, NATO } \\
\text { Security Force Assistance } \\
\text { Concept, dated 28 March 2014) }\end{array}$} & \multicolumn{2}{|c|}{$\begin{array}{c}\text { Доктрина } \\
\text { (AJP-3.16 Allied Joint Doc- } \\
\text { trine for Security Force } \\
\text { Assistance, Edition A Version 1) }\end{array}$} & $\begin{array}{c}\text { Керівництво } \\
\text { (NATO Special Opera- } \\
\text { tional Forses. Military } \\
\text { Assistance. HandBook) }\end{array}$ \\
\hline & \multicolumn{4}{|c|}{ Документн стратегічного рівня } \\
\hline $\begin{array}{c}\text { "Розвиток спроможно- } \\
\text { стей оборони і безпекн” } \\
\text { (Defence and Related } \\
\text { Security Capacity } \\
\text { Building Initiative } \\
\text { (DCB); PO(2013) } \\
\text { 0590-rev.1) }\end{array}$ & \multicolumn{2}{|c|}{$\begin{array}{l}\text { “'Завдання розвнтку } \\
\text { спроможностей оборонн } \\
\text { i безпекн” (Tasking on } \\
\text { Defense and Related } \\
\text { Security Capacity Building, } \\
\text { 02 December 2013; } \\
\text { PO (2010) 0169) }\end{array}$} & \multicolumn{2}{|c|}{$\begin{array}{l}\text { "План дій шодо всебічного під- } \\
\text { ходу" (РО (2011) 0045. Updated } \\
\text { List of tasks for the Implementation } \\
\text { of the Comprehensive Approach } \\
\text { Action Plan and the Lisbon Summit } \\
\text { Decisions on the Comprehensive } \\
\text { Approach, 04 March 2011) }\end{array}$} \\
\hline
\end{tabular}

Рис. 1. Керівні документи Security Force Assistance

Відповідно до цих документів, під SFA мається на увазі спроможність “тренувати та розвивати національні сили в кризових зонах" 3 метою досягнення спроможності щодо ефективної підтримки безпеки без міжнародної допомоги. До SFA віднесено всі дії, які розвивають, вдосконалюють або безпосередньо підтримують розвиток національних сил безпеки та оборони. SFA охоплює всі заходи, які спрямовані на розвиток і підготовку національного сектору безпеки i оборони, i проводиться на тактичному, оперативному, стратегічному і воєнно-політичному рівнях [13].

Відповідно до стандартів НАТО в межах SFA здійснюється: 
організація та проведення, відповідно до прийнятих в НАТО нормативів, цільових інструкторсько-методичних занять 3 підрозділами зі складу загальновійськових з'єднань, десантно-штурмових бригад, а також бойових груп сил спеціальних операцій;

ознайомлення військовослужбовців країн-партнерів 3 новими зразками озброєння, військової техніки, засобами зв'язку та навігації, іншим спеціальним обладнанням;

визначення рівня готовності формувань до бойових дій з урахуванням прийнятих в Альянсі нормативів.

Підготовка військовослужбовців загальновійськових і десантноштурмових формувань спрямовується на вдосконалення професійних навичок, що застосовуються під час ведення підрозділами дій в обороні і наступі. При цьому, особливий акцент робиться на підвищенні індивідуального польового вишкілу офіцерів і солдат.

Після закінчення навчального курсу уповноважені представники НАТО проводять атестацію (сертифікацію) підготовлених формувань Збройних Сил України i органів військового управління на предмет їх відповідності прийнятим в НАТО стандартам.

Зазвичай, до заходів SFA залучають викладачів військово-навчальних закладів і навчальних центрів, начальників загальновійськових полігонів i командирів військових частин. Ця категорія військовослужбовців цілеспрямовано вивчає прийняту в Альянсі методику організації занять 3 оперативної і бойової підготовки для подальшого впровадження отриманих знань в навчальну практику на місцях. Особливу увагу приділяють розвитку спроможностей сил спеціальних операцій (ССО). При цьому враховують реальні оперативні спроможності спецпідрозділів, призначених для виконання важливих завдань, в тому числі в умовах “гібридних" конфліктів.

Підготовку військовослужбовців підрозділів ССО здійснюють, виходячи із загальної специфіки застосування підрозділів (груп) спецпризначення в інтересах досягнення конкретних воєнно-політичних і воєнних цілей, зокрема, знищення стратегічних об'єктів противника, його ракетно-ядерної і ракетної зброї, ведення радіоелектронної розвідки, організації партизанського руху, проведення диверсій, ліквідації ключових представників державного і військового керівництва противника.

Упровадження передових методів і способів проведення спецзаходів відбувається $з$ урахуванням досвіду, отриманого в ході воєнних конфліктів. Приділяється увага і засадам проведення інформаційно-психологічних операцій, організації пропагандистських заходів, введення противника в оману, інформування мирного населення і дискредитації органів влади противника.

В інтересах закріплення досягнутих результатів бойового навчання, а також для визначення ступеня готовності військ (сил) до бойових дій в сучасних умовах, щорічно проводять багатонаціональні навчання. Сценарій навчань, зазвичай, передбачає виникнення в умовному районі кризових ситуацій, вирішення яких потребує втручання об’єднаних сил НАТО. 
Навчання військових та цивільних фахівців сектору безпеки і оборони здійснюється за напрямами: міжнародна і національна безпека, інформаційна та кібернетична безпека, проведення миротворчих операцій, розвідувальна діяльність, військова медицина, штабна і інженерна підготовка, підвищення кваліфікації офіцерів військової поліції, підготовка молодшого командного складу, вивчення іноземних мов, підготовка фахівців кадрових органів тощо.

Військовослужбовців країн-партнерів активно залучають до проведення спільних 3 Північноатлантичним союзом заходів оперативної i бойової підготовки на території держав-членів Альянсу. В ході цих навчань основну увагу приділяють питанням організації роботи об'єднаного штабу для всебічного забезпечення дій багатонаціонального формування.

Проведення під керівництвом радників заходів у рамках SFA, в тому числі навчань із залученням підрозділів сухопутних військ, повітряних і військовоморських сил, десантно-штурмових військ, сил спеціальних операцій, а також національної гвардії дають змогу:

підвищити рівень професійного вишкілу військовослужбовців, перш за все, зі складу загальновійськових з'єднань, десантно-штурмових бригад i морської піхоти;

розвивати спроможності ССО країн-партнерів, а також спецпідрозділів інших структур сектору безпеки і оборони;

забезпечувати постійну присутність на території країни-партнера контингенту військовослужбовців об’єднаних збройних сил НАТО, як радників, так й інструкторів.

Актуальним при цьому $\epsilon$ вдосконалення нормативно-правової бази, відповідно до якої чисельність іноземних військових радників може бути (за потреби) істотно збільшена до кількох тисяч осіб на весь термін проведення операції SFA.

У перспективі держави-члени НАTO в межах SFA планують продовжувати надавати допомогу і Україні з питань професійної підготовки військовослужбовців Збройних Сил України, оптимізації їх організаційноштатної структури та чисельності, модернізації системи управління, тилового, технічного та медичного забезпечення.

Така практика дає змогу НАТО, разом з предметним вивченням умов потенційного театру воєнних дій, знайомитися 3 досвідом, отриманим військовослужбовцями країн-партнерів під час виконання ними бойових завдань в ході воєнних конфліктів для його всебічного аналізу та використання під час підготовки об’єднаних збройних сил Альянсу.

Для цього визначені такі завдання:

бойова і оперативна підготовка національних підрозділів;

підготовка інструкторів 3 військовослужбовців національних збройних сил;

надання сприяння в обладнанні навчальних центрів на території країнпартнерів;

консультативна допомога 3 питань реформування збройних сил та їх послідовного приведення до стандартів НАТО. 
НАТО впроваджує дієву концепцію підтримки і розвитку спроможностей сектору безпеки і оборони та ефективні механізми ії імплементації в практичну сферу діяльності військ (сил), які дають змогу вирішувати широке коло проблем щодо забезпечення безпеки і оборони держав-партнерів, які не $\epsilon$ членами НАТО. Разом з тим, впровадження такої концепції потребує від країнпартнерів змін нормативно-правової бази та відповідної підготовки кадрів й інфраструктури.

Для цього держави-члени НАТО у подальшому планують надавати допомогу Україні в критично важливих сферах безпеки і оборони держави, особливо для вирішення таких проблем:

модернізація системи управління, комунікації та комп'ютеризації;

логістика та стандартизація Збройних Сил України;

кібербезпека;

перепідготовка та соціальна адаптація військовослужбовців;

медична реабілітація;

протидія саморобним вибуховим пристроям i знешкодження вибухонебезпечних предметів;

утилізація радіоактивних відходів.

У цьому контексті Україна розглядає наступні пріоритетні шляхи розвитку сил оборони:

реформа сектору безпеки і оборони;

демократичний цивільний контроль;

професійна військова освіта та розвиток напряму цивільних фахівців тощо.

В умовах, коли не можливо протидіяти російській “гібридній” агресії на повну потужність, вдосконалення співробітництва України 3 НАТО розглядається, як потенційний формат ключових партнерів (Велика Британія, Канада, Литва, Польща, США).

Однак, впровадження у Міністерстві оборони України, Збройних Силах України та інших складових сил оборони моделі оборонного планування на основі спроможності виявило низку проблем, які потребують більш детального вивчення та вирішення для сучасності. Наприклад, у США для впровадження ОПОС спочатку активно розробляли нові методики. Метою ОПОС визначено створення та розвиток необхідних оборонних спроможностей. Їх перелік, зокрема в НАТО, визначений Стратегічною концепцією щодо оборони та безпеки держав-членів НАТО. Важливим документом для імплементації іiі вимог набула прийнята державами-членами НАТО Комплексна політична директива (Comprehensive Political Guidance), яка забезпечує єдність підходів усіх членів Альянсу для досягнення спільної мети. Вона визначає пріоритети трансформації Альянсу, спрямовані на ефективне виконання операцій: вдосконалення спроможності, трансформацію сил i засобів, структурну реорганізацію, розвиток процесу генерування сил, а також їх спроможності, планування й розвідки та відповідне фінансування. На основі аналізу безпекового середовища, визначення джерел потенційних викликів та можливого реагування, застосування асиметричних засобів нападу, в цьому документі в узагальненому формулюванні визначаються види операцій та типи 
військових сил і засобів, необхідних для них. Сили, які залучаються для виконання операції, мають бути структуровані, оснащені, укомплектовані й підготовлені для операцій швидкого реагування. Ключовим елементом таких сил визнаються Сили реагування НАТО (CРH) (NATO Response Force), які ефективно підсилюють наявні сили під час всієї операції [13].

Комплексна політична директива також визначає конкретні вимоги щодо сил та засобів, яким члени Альянсу мають приділяти належну увагу як на індивідуальних, так і на колективних засадах, зокрема:

проводити і підтримувати багатонаціональні, об'єднані експедиційні операції на далекій відстані протягом тривалого часу за умов скоординованого та багатонаціонального підходу до тилового забезпечення;

швидко та ефективно адаптувати військову доктрину та плани дій у непередбачуваних обставинах;

стримувати та протидіяти терористичним нападам, забезпечувати антитерористичну оборону та захист;

забезпечувати захист найважливіших систем Альянсу від кібернетичних нападів;

проводити операції з урахуванням ракетної загрози та засобів масового ураження;

визначати ворожі елементи для мінімізації небажаних руйнувань і ризику безпеці сил;

проводити операції 3 високим рівнем гнучкості, що передбачає координацію всіх учасників операції, особливо коли одночасно мають бути реалізовані заходи бойового, стабілізаційного, відновлювального, примирювального та гуманітарного характеру;

забезпечити високий рівень оперативної сумісності та стандартизації між членами Альянсу та країнами-партнерами.

Розвиток спроможності Збройних Сил України та інших складових сил оборони потребує достатніх ресурсів, які передбачається отримати за рахунок збільшення інвестицій у розвиток ключових спроможностей. Для цього доцільно періодично переглядати пріоритети та ефективніше використовувати наявні ресурси.

Висновок та перспективи подальших досліджень. Досліджений досвід та підходи НАТО у оборонній та військовій сферах мають істотне значення для їх використання у оборонній сфері та сфері військової освіти і підготовки військових кадрів в Україні, а також для розроблення у Міністерстві оборони України, Збройних Силах України та інших складових сил оборони відповідних концептуальних документів, програм і планів для наближення цих процесів до принципів і стандартів, прийнятих в державах-членах НАТО. У подальшому доцільно застосовувати ефективні підходи НАТО у сфері оборони та військової освіти, наблизивши цей процес до принципів і стандартів, прийнятих у арміях держав-членів НАТО. Головна мета цієї діяльності у сфері воєнної освіти полягає у здобутті нових наукових знань у сфері національної безпеки і оборони шляхом проведення наукових досліджень та розробок, спрямованих на вирішення проблем забезпечення обороноздатності України, створення та 
впровадження нової конкурентоспроможної наукової та науково-технічної продукції, підвищення якості підготовки військових фахівців та наукових i науково-педагогічних кадрів [8].

\section{ЛІТЕРАТУРА}

1. План дій щодо впровадження оборонної реформи на 2019-2020 роки: затверджений міністром оборони України, головою Комітету реформ Міністерства оборони України та Збройних Сил України 23.01.2019 року.

URL:https://www.mil.gov.ua/content/oboron_plans/2019.01.23_Plan_diy_2019-2020.pdf

2. Руснак I. С., Петренко А. Г., Яковенко А. В., Романюк І. М., Кохно В. Д. Оборонне планування на основі спроможностей: особливості та перспективи впровадження. Наука $\mathrm{i}$ оборона. 2017. № 2. C. 3-10. URL:http://nio.nuou.org.ua/article/view/176927

3. Петренко А. Г. Щодо впровадження оборонного менеджменту та управління змінами в Міністерстві оборони України. Наука і оборона. 2019. № 2. С. 3-8. URL:http://nio.nuou.org.ua/article/view/179715

4. Оборонна реформа: системний підхід до оборонного менеджменту: монографія / А. Павліковський, В. Фролов, Ф. Саганюк, Ю.Мудрак та ін.; за заг. ред. д-ра військ. наук А. Сиротенка. Київ: НУОУ ім. Івана Черняховського, 2020. 274 с. URL:https://nuou.org.ua/assets/monography/mono-obo-ref-2020.pdf

5. Павліковський А.К., Іващенко А. М. Аналіз основних напрямків розвитку оперативних спроможностей Північноатлантичного Альянсу після Варшавського саміту. Зб. наук. праць ЦВСД. К.: НУОУ ім. Івана Черняховського, 2016. № 3 (58). С. 18-23. URL:http://znp-cvsd.nuou.org.ua/article/view/126013

6. Міністерство оборони України: офіційний вебсайт. 2020. URL:https://www.mil.gov.ua/news/2020/08/26/ministr-oboroni-andrij-taran-vruchiv-generalskizvannya-ta-derzhavni-nagorodi-vijskovosluzhbovczyam-ta-praczivnikam-zs-ukraini/

7. Міністерство оборони України: офіційний вебсайт. 2020. URL:https://www.mil.gov.ua/news/2020/10/30/funkczionuvannya-zsu-do-kinczya-2022-rokubudut-perevedeni-na-novu-doktrinalnu-bazu-andrij-taran/

8. Офіційний вебсайт НУОУ імені Івана Черняховського. URL: https://nuou. org.ua/u/news/privtannya-nachalnika-unversitetu-z-nagodi-dnya-nauki.html

9. Брежнєва Т.К. Імплементація "Комплексної політичної директиви НАТО” як нового стратегічного документа. Стратегічні пріоритети. 2009. № 1 (10). С. 218-227.

10. Дєнєжкін М. М., Наливайко А. Д., Поляєв А. І. Особливості оборонного планування у державах-членах НАТО, на основі спроможностей. Зб. наук. праць ЦВСД НУОУ, 2017. № 2 (60). C. 34-38. URL:http://znp-cvsd.nuou.org.ua/issue/view/7396

11. Наливайко А. Д., Сівоха І. М., Поляєв А. І. Впровадження оборонного планування на основі спроможностей в складових сил оборони України. Зб. наук. праць ЦВСД НУОУ, 2018. № 1 (62). C. 46-50. URL:http://znp-cvsd.nuou.org.ua/issue/view/7398

12. Шляхи міжнародної колективної і коаліційної протидії “гібридній” агресії / Воєнні аспекти протидії “гібридній” агресії: досвід України: монографія / колектив авторів; за заг. ред. А. М. Сиротенка. К.: НУОУ, 2020. 176 с.

URL:https://nuou.org.ua/assets/monography/mono_gibr_viin.pdf

13. Comprehensive Political Guidance. Endorsed by NATO Heads of State and Government on 29 November 2006. Riga. Latvia. Part 3. §11.

URL:https://www.nato.int/cps/en/natohq/official_texts_56425.htm

\section{REFERENCES}

1. Plan diy shchodo vprovadzhennya oboronnoyi reformy na 2019-2020 roky: zatverdzhenyy ministrom oborony Ukrayiny, holovoyu Komitetu reform Ministerstva oborony Ukrayiny ta Zbroynykh Syl Ukrayiny 23.01.2019 roku [Action plan for the implementation of defense reform 
for 2019-2020: approved by the Minister of Defense of Ukraine, Chairman of the Reform Committee of the Ministry of Defense of Ukraine and the Armed Forces of Ukraine on January 23, 2019]. URL:https://www.mil.gov.ua/content/oboron_plans/2019.01.23_Plan_diy_2019-2020.pdf

2. Rusnak I.S, Petrenko A.G, Yakovenko A.V, Romanyuk I.M, Kokhno V.D. Oboronne planuvannya na osnovi spromozhnostey: osoblyvosti ta perspektyvy vprovadzhennya [Capabilitybased defense planning: features and implementation prospects]. Nauka i oborona. 2017. № 2. p. 310. URL:http://nio.nuou.org.ua/article/view/176927

3. Petrenko A.G. Shchodo vprovadzhennya oboronnoho menedzhmentu ta upravlinnya zminamy v Ministerstvi oborony Ukrayiny [Regarding the introduction of defense management and change management in the Ministry of Defense of Ukraine]. Nauka i oborona. 2019. № 2. p. 3-8. URL:http://nio.nuou.org.ua/article/view/179715

4. Oboronna reforma: systemnyy pidkhid do oboronnoho menedzhmentu: monohrafiya [Defense reform: a systematic approach to defense management: a monograph]. A. Pavlikovsky, V. Frolov, F. Saganyuk, Y. Mudrak and others; for general ed. Dr. Troops. Sciences A. Sirotenko. Kyiv: National Defence University of Ukraine, 2020. 274 c. URL:https://nuou.org.ua/assets/monography/mono-obo-ref-2020.pdf

5. Pavlikovsky A.K., Ivashchenko A.M. Analiz osnovnykh napryamkiv rozvytku operatyvnykh spromozhnostey Pivnichnoatlantychnoho Al'yansu pislya Varshavs'koho samitu [Analysis of the main directions of development of operational capabilities of the North Atlantic Alliance after the Warsaw Summit]. Collection of scientific works Center for Military Strategic Studies. K.: National Defence University of Ukraine named after Ivan Cherniakhovskyi, 2016. № 3 (58). p. 18-23. URL:http://znpcvsd.nuou.org.ua/article/view/126013

6. Ministerstvo oborony Ukrayiny: ofitsiynyy vebsayt [Ministry of Defense of Ukraine: official website]. 2020. URL:https://www.mil.gov.ua/news/2020/08/26/ministr-oboroni-andrijtaran-vruchiv-generalski-zvannya-ta-derzhavni-nagorodi-vijskovosluzhbovczyam-ta-praczivnikamzs-ukraini/

7. Ministerstvo oborony Ukrayiny: ofitsiynyy vebsayt [Ministry of Defense of Ukraine: official website]. 2020. URL:https://www.mil.gov.ua/news/2020/10/30/funkczionuvannya-zsu-dokinczya-2022-roku-budut-perevedeni-na-novu-doktrinalnu-bazu-andrij-taran/

8. Ofitsiynyy vebsayt Natsional'noho universytetu oborony Ukrayiny imeni Ivana Chernyakhovs'koho [National Defence University of Ukraine named after Ivan Cherniakhovskyi: official website].

URL: https://nuou. org.ua/u/news/privtannya-nachalnika-unversitetu-z-nagodi-dnya-nauki.html

9. Brezhneva T.K. Імплементація "Комплексної політичної директиви НАТО” як нового стратегічного документа [Implementation of the NATO Comprehensive Policy Directive as a new strategic document]. Stratehichni priorytety. 2009. № 1 (10). p. 218-227.

10. Denezhkin M.M., Nalyvayko A.D., Polyaev A.I. Osoblyvosti oboronnoho planuvannya u derzhavakh-chlenakh NATO, na osnovi spromozhnostey [Features of defense planning in NATO member states, based on capabilities]. Collection of scientific works Center for Military Strategic Studies National Defence University of Ukraine, 2017. № 2 (60). p. 34-38. URL:http://znpcvsd.nuou.org.ua/issue/view/7396

11. Nalyvayko A.D., Sivokha I.M., Polyaev A.I. Vprovadzhennya oboronnoho planuvannya na osnovi spromozhnostey v skladovykh syl oborony Ukrayiny [Implementation of capability-based defense planning in the defense forces of Ukraine]. Collection of scientific works Center for Military Strategic Studies National Defence University of Ukraine, 2018. № 1 (62). p. 46-50. URL:http://znp-cvsd.nuou.org.ua/issue/view/7398

12. Shlyakhy mizhnarodnoyi kolektyvnoyi i koalitsiynoyi protydiyi "hibrydniy" ahresiyi / Voyenni aspekty protydiyi "hibrydniy" ahresiyi: dosvid Ukrayiny: monohrafiya [Ways of international collective and coalition counteraction to "hybrid" aggression / Military aspects of counteraction to "hybrid" aggression: experience of Ukraine: monograph]. Team of authors; for 
general ed. AM Sirotenko. K.: National Defence University of Ukraine, 2020. 176 p. URL:https://nuou.org.ua/assets/monography/mono_gibr_viin.pdf

13. Comprehensive Political Guidance. Endorsed by NATO Heads of State and Government on 29 November 2006. Riga. Latvia. Part 3. §11.

URL:https://www.nato.int/cps/en/natohq/official_texts_56425.htm

\title{
PЕЗЮМЕ
}

Николай Иваницкий

кандидат военных наук, доцент кафедра руководства войсками (силами) в мирное время

Национальный университет обороны Украины имени Ивана Черняховского, г.Киев

Юрій Мудрак

Центр военно-стратегических исследований Национальный университет обороны Украины имени Ивана Черняховского, г.Киев

Юрій Піщанський

Центр военно-стратегических исследований Национальный университет обороны Украины имени Ивана Черняховского, г.Киев

\section{Пути приближения оборонной и военно-образовательной сфер Украины к стандартам НАТО}

\begin{abstract}
В статье рассмотрен опыт НАТО в сферах обороны и военного образования с целью его использования при планировании развития Министерства оборонь Украинь, Вооружённых Сил Украины и других составляющих сил обороны, и приближение их функционирования $\kappa$ принципам $u$ стандартами, принятыми в армиях государств-членов НАТО.
\end{abstract}

Ключевые слова: военное образование, Вооруженные Сильл Украины; подготовка; способности.

\section{SUMMARY}

Mykola Ivanytskyi

Candidate of Military Sciences, Assistant professor Department of Command of Troops (Forces) in peacetime

National Defence University of Ukraine named after Ivan Cherniakhovskyi, Kyiv

Yurii Mydrak

Center for Military Strategic Studies National Defence University of Ukraine named after Ivan Cherniakhovskyi, Kyiv

Yurii Pishchanskyi

Center for Military Strategic Studies National Defence University of Ukraine named after Ivan Cherniakhovskyi, Kyiv

\section{Ways of approaching Ukraine's defense and military education area to NATO standards}

The article examines NATO's experience in defense and military education in order to use it in planning the development of the Ministry of Defense of Ukraine, the Armed Forces of Ukraine and other defense forces, and bringing their functioning closer to the principles and standards adopted by NATO member armies. 
Key words: military education, Armed Forces of Ukraine; preparation; capacity.

Introduction. The ongoing defense reform in Ukraine aims to acquire and maintain the required level of combat readiness and ability to perform state defense tasks (defense capabilities), respond effectively to emerging military threats and military-political challenges to national security, and increase the level of interoperability. Of the Armed Forces of Ukraine and other military formations with units of the Armed Forces of NATO and EU member states to perform joint tasks in international peacekeeping and security operations.

Education in this military business is the basis of intellectual, spiritual, physical and cultural development of the individual, his successful socialization, economic well-being, the key to the development of a society united by common values and culture, and the state.

The transfer of administrative processes and principles of functioning of the Armed Forces of Ukraine to a new doctrinal base by the end of 2022 is an ambitious goal of defense reform. This requires the training of professionals capable of acting in accordance with its provisions. A new style of military leadership, a new philosophy of relations in military teams, as well as a change in military culture should be introduced in the Armed Forces of Ukraine.

Purpose: The purpose of the article is to search for effective approaches to solving the tasks set by the Ministry of Defense of Ukraine, bringing the development of the Armed Forces of Ukraine closer and their functioning to the principles and standards adopted in the armies of developed NATO member states.

Results. Training of military and civilian specialists in the security and defense sector is carried out in the following areas: international and national security, information and cyber security, peacekeeping operations, intelligence activities, military medicine, staff and engineering training, advanced training of military police officers, training of junior command staff, study foreign languages, training of personnel specialists, etc.

The troops of Partner countries are actively involved in joint operational and combat training activities with the Alliance in the Alliance. These exercises focus on organizing the work of the Joint Staff to fully support the actions of the multinational formation.

NATO implements an effective concept for supporting and developing the capabilities of the security and defense sector and effective mechanisms for its implementation in the practical field of operations of forces (forces), which allow solving a wide range of security and defense problems of non-NATO Partner countries. At the same time, the implementation of such a concept requires partner countries to change the regulatory framework and appropriate training and infrastructure.

In conditions when it is not possible to counter Russia's "hybrid" aggression at full capacity, improving Ukraine's cooperation with NATO is seen as a potential format for key partners (UK, Canada, Lithuania, Poland, USA).

Capacity development of the Armed Forces also requires sufficient resources, which are expected to be obtained by increasing investment in the development of key capabilities. To do this, it is advisable to periodically review priorities and make better use of available resources.

Conclusion. NATO's research experience and approaches in the defense and military spheres are essential for their use in defense and military education and training in Ukraine, as well as for the development of relevant concept papers in the Ministry of Defense of Ukraine, the Armed Forces of Ukraine and other defense forces. , programs and plans to bring these processes closer to the principles and standards adopted in NATO member states.

In further research on this issue, it is advisable to apply effective NATO approaches in the field of defense and military education, bringing this process closer to the principles and standards adopted in the armies of NATO member states.

The main purpose of this activity in the field of military education is to acquire new scientific knowledge in the field of national security and defense by conducting research and development aimed at solving the problems of ensuring Ukraine's defense capabilities, creation and introduction of new competitive scientific and scientific and technical products, improving the quality of training of military specialists and scientific and scientific-pedagogical personnel. 